\title{
HAK KESEJAHTERAAN PROGRESIF UNTUK BURUH
}

\author{
Anik Malikah \\ Fakultas Ekonomi Universitas Islam Malang (UNISMA) \\ E-mail: Amapf24@yahoo.com
}

\begin{abstract}
The development of human rights (HAM) from labor is already experiencing an increase in some aspects, such as wage labor rights, but this improvement or development is still not balanced if associated with rapidly growing labor daily needs, especially the needs of the tree, so labor still get to enjoy the rights and wellbeing progresifitasnya compared with general operators can get more than enough profit.
\end{abstract}

Keywords: rights, labor, welfare, operators

\section{PENDAHULUAN}

Peringatan hari buruh pada awalnya dilatarbelakagi oleh pengetatan disiplin dan pengintensifan jam kerja, minimnya upah dan buruknya kondisi kerja di tingkat pabrik sehingga melahirkan perjuangan buruh untuk meraih kendali ekonomi, hak politik, dan hak industrial. Hingga saat ini, tanggal 1 Mei ditetapkan menjadi hari buruh dan dikenal dengan istilah May Day dan diperingati kaum buruh di berbagai Negara (Oksidelfa Yanto, 2013)

Di Indonesia, May Day atau Labour Day pertama kali diperingati pada tahun 1920. Sejak peristiwa G-30 S PKI hal itu tidak diperingati lagi, karena pergerakan buruh dihubung-hubungkan dengan paham komunis. Baru pada 1999, setelah berakhirnya masa pemerintahan Orde Baru, hari buruh kembali diperingati. Berbagai macam organisasi buruh lahir sebagai kekuatan yang relatif independen. Namun, gerakan buruh era reformasi menghadapi tantangan yang kian berat. Ia harus menghadapi kepentingan negara dan pengusaha (Oksidelfa Yanto, 2013, Abdul Haris, 2013).

Kini, sebuah terobosan telah dilakukan Presiden Susilo Bambang Yudhoyono (SBY) yang menjanjikan peringatan 1 Mei menjadi hari libur nasional mulai 2014. Bagaimanapun Hari Buruh Sedunia pada intinya bermakna sebagai momentum untuk memperjuangkan kondisi kerja yang lebih baik dengan caracara damai. Dari jam kerja yang semula 16 jam per hari menjadi 8 jam, dari kondisi kerja paksa atau perbudakan menjadi kerja yang manusiawi. (Abdul Haris, 2013).

Meskipun begitu, buruh tetap saja melakukan aksi-aksi dan tuntutantuntutan melalui demonstrasi. Aksi damai dan tuntutan buruh pada dasarnya tidak terlepas dari masalah kesejahteraan kaum buruh terutama dalam aspek ekonomi. Tuntutan itu ditujukan kepada pemerintah dan perusahaan tempat buruh bekerja. Ketidakpuasan akan kesejahteraan yang mereka dapatkan sebagai buruh,

This work is licensed under Creative Commons Attribution Non Commercial 4.0 International License Available online on: http://riset.unisma.ac.id/index.php/natiq/index 
mendorong para buruh untuk mendapatkan hak-hak mereka lewat demonstrasi pada setiap 1 Mei. Tuntutan akan kesejahteraan yang lebih baik adalah hal yang wajar mengingat beratnya biaya hidup dengan upah yang masih rendah. Betapa tidak, di saat harga-harga kebutuhan pokok terus saja melambung tinggi, tetapi upah yang mereka terima sangat minim dan kecil sekali. Bagi buruh, kenaikan harga kebutuhan pokok sudah pasti akan memberatkan (Oksidelfa Yanto, 2013).

\section{PEMBAHASAN}

\section{Logika Progresivitas}

Sejak masa Soeharto hingga pemerintahan Yudhoyono saat ini, politik upah murah terus saja dijalankan. Di masa Soeharto, politik upah murah dijadikan daya tarik untuk menarik investasi asing. Begitu pula saat ini, bahkan ditambah "embelembel", apabila upah buruh tinggi, pengangguran akan semakin meningkat. Jadi upah buruh murah harus dijalankan untuk mengatasi pengangguran dan menciptakan lapangan kerja. Penciptaan lapangan kerja dianggap lebih penting daripada meningkatkan kesejahteraan pekerja. (Oksidelfa Yanto, 2013)

Jika berbicara mengenai upah, untuk ukuran provinsi, Jakarta merupakan provinsi dengan upah tertinggi. Pada 2006, UMP Jakarta Rp819.100 bulan. Dewan Pengupahan DKI menaikkan UMP Jakarta menjadi Rp 900.560 per bulan untuk 2007. Namun, para aktivis buruh menilai kenaikan upah 9,95\% itu terlalu rendah. Anwar Ma'ruf, Koordinator Aliansi Buruh Menggugat, mengatakan upah Rp900-an ribu per bulan belumlah layak karena UU Ketenagakerjaan mengatur agar upah ditentukan berdasarkan kebutuhan hidup layak. Dengan demikian, untuk ukuran Kota Jakarta, upah yang RP900-an ribu per bulan belum layak untuk tercapainya kesejahteraan hidup (Oksidelfa Yanto, 2013). Upah yang di tentukan berdasarkan kebutuhan hidup ini mengandung konsekuensi yang berujung pada pemenuhan hak yang bersifat progresif. Artinya dari upah yang bersifat rendah pada buruh, dituntut selalu secepatnya bisa disesuaikan dengan perkembangan kebutuhan (Ahsan Abdullah, 2013)

Meski seharusnya ada keseimbangan antara upah dengan kebutuhan buruh, akan tetapi yang terjadi berbeda. Dari jumlah upah yang diterima kaum buruh pada umumnya menunjukkan bahwa pendapatan yang diterima oleh masyarakat yang berprofesi sebagai buruh masih relatif rendah Kondisi ini semakin mempersulit kaum buruh untu meningkatkan Kesejahteraan yang secara progresif memang haru menjadi miliknya buruh, justru beralih menja miliknua perusahaan. (Oksidelfa Yanto, 2013, Ahsa taraf kesejahteraannya Abdullah, 2013)

Perkembangan hak pengupahan buruh di Jakarta misalnya sekurangkurangnya dimulai tahun 2010 sudah mengalami peningkatan, akan tetapi peningkatan atau perkembangan ini masih tetap belum seimbang jika dikaitkan dengan perkemmbangan kebutuhan sehari-hari buruh terutama kebutuhan pokoknya, sehingga buruh masih belum mendapatkan dan menikmati hak 
kesejahteraan progresifitasnya, padahal pada hak progresifitsnya inilah kesejahterannya menjadi lebih berarti.

\section{Membaca Fakta dan Komitmen Pemerintah}

Selama ini perusahaan masih menganggap buruh sebagai mesin produksi penghasil uang dan cenderung mengabaikan aspek kemanusiaan. Kaum buruh sering dijadikan bahan eksploitasi untuk kepentingan bisnis semata (Oksidelfa Yanto, 2013). Buruh ditempatkan sebagai mesin utama perusahaan dari sisi mendatangkan dan mengembangkan keuntungan, namun di sisi kemanusiaan, buruh tidak ubahnya diperlakukan seperti budak (Munir Ramadan, 2011)

Kondisi buruh di banyak perusahaan di Indonesia masih jauh dari standar sejahtera. Apalagi dengan munculnya budaya populer di berbagai perusahaan akhir-akhir ini yang hanya menjadikan buruh sebagai tenaga-tenaga kontrak dan setiap saat bisa diputuskan hak ekonominya tanpa perlindungan yang menguntungkan dari negara. Kondisi ini semakin meneguhkan kepada kita bahwa buruh tidak mendapatkan penghargaan atas kerja keras dan jerih payahnya dalam memajukan sebuah perusahaan. Buruh lebih sering dilihat sebagai anatomi perusahaan dan bukan anatomi kemansuiaan. (Oksidelfa Yanto, 2013, Munir Ramadan, 2011))

Kiranya perlulah disadari bahwa, perusahaan yang baik adalah perusahaan yang memberikan kesejahteraan kepada buruhnya. Perusahaan harus menghargai buruh sebagai investasi. Hal ini menuntut konsekuensi, bahwa, hendaknya semua pihak mendukung peningkatan kesejahteraan buruh. (Oksidelfa Yanto, 2013)

Persoalan ini harus menjadi komitmen pemerintah dan pelaku usaha. Hanya dengan memberikan kesejahteraan yang layak kepada buruh, maka suatu perusahaan akan maju dan berkembang. Tanpa buruh, perusahaan akan mati. Tanpa buruh, perusahaan tidak akan berjalan. Sekali lagi ini harus disadari oleh semua pihak. (Oksidelfa Yanto, 2013). Sayangnya, perusahaan masih banyak yang belum berfikir demikian. Terbukti upah buruh di Indonesia yang terendah dibanding negara tetangga di ASEAN. Fadli Zon menyatakan, Thailand memiliki upah minimum ekuivalen Rp 2,1 juta - Rp 2,8 juta, Malaysia Rp 2,4 juta, dan Filipina Rp 3 juta. Sementara Indonesia, upah buruh rata- rata masih di bawah Rp 2 juta. Hanya Jakarta saja yang sudah di atas Rp 2 juta, itupun belum dilakukan semua perusahaan (Fajar-Online, 1 Mei 2013)

Jika para buruh sejahtera, tentu saja buruh tidak memiliki beban dalam menjalani hidupnya. Pada akhirnya tidak akan ada demo-demo para buruh yang sebenarnya akan menghentikan kegiatan produksi di perusahaan-perusahaan. Ini akan merugikan perekonomian secara nasional.

Perusahan harus berkomitmen untuk menyejahterakan buruhnya. Perusahaan hendaknya memberikan upah yang layak untuk buruh dalam memenuhi kebutuhan hidupnya. Yang tidak kalah pentingnya, sudah saatnya perusahan menyediakan atau memberikan fasilitas tempat tinggal yang layak huni 
untuk buruh dan keluarganya. Tempat tinggal yang layak tersebut bisa disediakan di lokasi terdekat di mana buruh bekerja, sehingga akan lebih dekat dan tidak memerlukan ongkos atau biaya transportasi. Kondisi ini seringkali terabaikan oleh korporasi atau perusahaan. Perusahaan tidak mau berfikir yang berujung memberatkan dirinya. (Oksidelfa Yanto, 2013, Ahsan Abdullah, 2013)

Di samping itu, sudah seharusnya perusahaan memberikan fasilitas pendidikan kepada anak-anak buruh, memberikan jaminan sosial berupa asuransi kesehatan dan asuransi jiwa serta memberikan tunjangan hari tua untuk buruh. Jaminan sosial jangan hanya diberikan kepada mereka yang bekerja di sektor formal saja, tetapi juga hendaknya diberikan kepada mereka yang bekerja di sektor informal (Oksidelfa Yanto 2013)

Semua poin di atas harus menjadi perhatian an pihak yang berkepentingan, sebab buruh merupakan tulang punggung dalam setiap perusahaan, karena merekalah yang akan menjalankan perusahaan secara teknis dan operasional. (Oksidelfa Yanto, 2013)

Pendekatan Islam Indonesia adalah negara besar dengan dua juta lebih jumlah penduduk dan lebih dari $85 \%$ penduduk adalah penganut agama Islam. Dari sejumlah $85 \%$ angkat tersebut, lebih dari $50 \%$ adalah buruh yang terdiri dari buruh pabrik, buruh lepas, buruh tani, buruh pasar, buruh nelayan dan lain-lain. Sehingga artinya, ketika kita bicara soal hak buruh di Indonesia maka secara otomatis kita sedang membicarakan hak-hak kaum muslimin di Indonesia (Eko Riyadi, 2012)

Syed Abdul Hamid Junaid menulis mengenai faktor produksi dengan judul factors of production and factor pricing from an Islamic perpective. Ia mengungkapkan empat faktor produksi yang penting dalam melakukan produksi. Empat fakta produksi tersebut adalah tenaga kerja/buruh (labour), tanah (natural resources), modal (capital) dan entrepreneur. Hal ini sejalan dengan pandangan Afzalur Rahman dalam Doktrin Ekonomi Islam, Syed Abdul Hamid Junaid mengungkapkan buruh atau manusia mempunyai peranan yang lebih penting dibanding faktor produksi yang lain; tanah, modal, dan entrepreneur Manusia mempunyai kekuasan untuk menyusun faktor produksi yang lain dalam berbagai bentuk guna memenuhi kepentingan manusia, walaupun ia sebagai buruh. Modal, tanah, dan enterpreneur dianggap given, dimana fungsinya tergantung bagaimana manusia mengunakannya. Oleh karena dalam Islam menganjurkan agar pengusaha untuk mefungsikan buruh secara proporsional, dimana manfaat dari faktor produksi tidak sekedar dinilai dari besarnya hasil yang dicapai dari manfaat faktor produksi dalam setiap produksi. Karenanyal kebanyakan pengusaha lebih mempertimbangkan hasil yang dicapai dari pemanfaatan modal, tanah dan organisasi dibanding dengan pemanfaatan buruh. (Sudarsono, 2007)

Tujuan yang diharapkan buruh adalah upah yang sesuai dan kesejahteraan yang memadai, sedangkan bagi pemilik modal berkembangnya usaha dan mendapatkan keuntungan yang diinginkan. Kesimpulannya kedua belah pihak 
dalam kedudukan yang sama-sama menanggung keuntungan dan kerugian. ( Fadly Rahman, 2009)

Beberapa pengusaha memahami buruh bukan sebagai unsur yang harus pelihara sebagai "aset" usaha. Dimana ia harus dididik dan dihargai sebagai faktor yang mempunyai kontribusi besar bagi produksi. Tetapi buruh dianggap sebagai bagian alat yang mempunyai fungsi untuk dapat menghasilkan output dengan ketentuan-ketentuan yang telah diatur oleh target produksi. Sehingga penghargaan terhadap buruh lebih didasarkan atas aturan-aturan tersebut daripada penghargaan ia sebagai manusia yang mempunyai hak kebebasan untuk melakukan "improvisasi" (Sudarsono, 2007)

Dalam sebuah hadis qudsi yang diriwaya oleh Imam Bukhari, Allah SWT mengingat siapapun, khususnya pengusaha yang berhubun dengan buruh, bahwa "di antara 3 kelompok yang dibenci oleh-Nya di hari kiamat adalah (majikan) yang mempekerjakan buruh, lalu buruh tersebut bekerja dengan penuh kesungguhan, namun orang (majikan) tersebut tidak memberinya upah (atau memberi upah namun tidak layak dan tidak sesuai dengan kontribusinya)". (Hafiduddin, 2006)

Dalam Hadis itu juga dapat dipahami, bahwa buruh atau pekerja, wajib hukumnya untuk diperlakukan secara manusiawi atau dipenuhi hak haknya. Mulai dari sandang, pangan, dan kebutuhan buruh lainnya, majikan atau tuan (perusahaan) terikat secara moral keagamaan untuk memenuhinya. Memenuhi hak-hak buruh bukan hanya menjalankan kewajiban dalam hubunganny dengan manusia (buruh), tetapi juga meneguhkan hubungan dengan Allah SWT.

Perlakuan yang menjauhkan buruh dari tindak kekerasan secara fisik maupun psikologis. Perlakuan yang bercorak menyakiti atau kebiadaban layak disebut sebagai perlakuan yang tidak memanusiakan buruh atau merampas hakhak buruh, sehingga bisa digolongkan bentuk perbuatan melanggar hak buruh sebagai manusia.

Islam menetapkan hak-hak yang menjamin kehidupan yang baik dan mulia bagi buruh. Sebagian hak-hak buruh menurut Islam: 1) Perjanjian yang jelas secara lisan maupun tulisan, jelas dan transparan, dan berkeadilan. Buruh juga harus mengetahui tugas dan tanggung jawab, juga hak dan kewajiban. 2) Persamaan martabat pekerjaan terhadap Buruh, tidak ada pekerjaan halal yang merendahkan ai $\mathrm{n}$ at martabat Buruh. 3) Buruh tidak diperbolehkan bekerja yang tidak sesuai dan diluar batas kemampuan. Khusus buruh wanita diberikan pekerjaan yang layak dan cocok bagi Buruh wanita. 4) Biaya pengobatan yang layak apabila terjadi kecelakaan kerja 5) Mempunyai waktu bekerja dan waktu luang untuk diri sendiri serta keluarga. 6) Upah yang layak dan tepat waktu dalam pembayaran 7) Buruh berhak dalan berserikat dan berkumpul serta mengeluarkan pendapatnya. Serikat buruh bertujuan membantu buruh dalam mencari keadilan dan mensosialisasi pekerjaan sesuai kesepakatan bersama ( Fadly Rahman, 2009)

Selain itu, Islam juga menyebutkan tentang kewajiban Buruh terhadap pemilik modal 1) Tanggung jawab buruh terhadap upah yang diminta dari pemilik 
modal dan upah tersebut sesuai dengan pekerjaan dan kemampuan Buruh ..Jangan sampai pemberian upah mengakibatkan pemilik modal mengalami kerugian. Apabila hal itu terjadi Buruh juga harus ikut mempertanggung jawabkan. Dalam Islam besar kecilnya upah berdasarkan perbedaan jenis pekerjaan, kemampuan, keahlian dan pendidikan. 2) Kesungguhan Buruh dalam melaksanakan pekerjaanya, yakni melaksanakan pekerjaan yang telah ditetapkan berdasarkan kesepakatan bersama antar buruh dan pemilik Modal. 3) Buruh wajib melaksanakan perintah pemilik modal serta yang mewakilinya sesuai dengan pekerjaan yang telah disepakti. Apabila menyimpang, Buruh tidak wajib mengikutinya: kecuali terdapat dalam perjanjian bersama. 4) Menjaga dan memelihara perlengkapan dan peralatan pekerjaan. Menjaga seluruh rahasia perusahaan dan pemilik modal sampai Buruh tidak lagi bekerja atau memutuskan hubungan kerja. (Fadly Rahman, 2009)

Dalam Islam tersebut sudah jelas digariskan, bahwa buruh bukanlah obyek perilaku biadab majikan atau korporasi, tetapi pilar kehidupan yang wajib dimanusiakannya yang mempunyai kedudukan sederajat dengan majikan dalam pandangan Allah, meskipun dalam realitas kehidupan kemasyarakat, khususnya dalam status perekonomian, ada perbedaan.

Terma mustadh 'afiin adalah terma yang terdapat dalam Al-Qur'an untuk menggambarkan sekelompok masyarakat yang lemah dan dilemahkan. Lemah dalam arti dia tidak memiliki kedaulatan yang penuh atas dirinya sendiri. Kehidupannya tergantung pada orang lain. Ketergantungan itu bisa dalam hal ekonomi, terdzalimi oleh kekuasaan, dan lemah secara pribadi. Secara legal, orang yang digolongkan sebagai kaum lemah antara lain fakir, miskin dan muallaf, maka bagi mereka berhak untuk mendapatkan pembagian zakat. Dalam tulisan ini, para buruh diklasifikasi sebagai kelompok lemah karena kondisi mereka yang fakir dan miskin. (Eko Riyadi, 2012)

Buruh atau pekerja dikategorikan sebagai mustadh'afiin menurut konsepsi Al-Qur'an minimal karena dua alasan, pertama, posisi mereka sangat lemah secara ekonomi. Kehidupan mereka tergantung pada sang majikan (pemilik modal). Majikan bisa memecat atau melakukan pemutusan hubungan kerja (PHK), atau para buruh kapan saja dengan alasan bangkrut dan berbagai alasan lain. Kedua, para buruh tidak mendapatkan perlindungan vang cukup dari negara atas perlindungan ketimpangan dan ketidakadilan yang mereka dapatkan dari majikan. Alih-alih memberikan perlindungan, negara (pemerintah Indonesia), justru melakukan penindasan dengan membuat regulasi yang berpihak kepada majikan. Kedua alasan di atas merupakan alasan substantif yang menjadi pekerjaan rumah bagi umat muslin di Indonesia untuk memperhatikan nasib kaum buruh. (Eko $\mathrm{h}$ Riyadi, 2012)

Islam menempatkan kaum lemah (mustadh'afiin) sebagai pihak yang harus dilindungi dan diberikan akses terhadap ekonomi yang memadai. Kaum lemah selalu diberi porsi oleh Allah sebagai orang yang berhak mendapatkan rizki dari 
orang lain. Mereka ditempatkan sebagai orang yang berhak mendapatkan pembagian zakat (baik zakat fitrah maupun zakat maal), mereka berhak mendapatkan makanan sebagai hukuman bagi orang yang melakukan dhihar kepada istrinya dan orang yang melakukan hubungan seksual dengan istrinya pada siang hari di bulan ramadhan. Masyarakat yang dalam kondisi lemah atau untuk mendapatkan dilemahkan berhak perlindungan, baik perlindungan dari penyiksaana maupun perlindungan dalam hal ekonomi. (Eko Riyadi, 2012)

Dengan status kesederajatan dan egalitarianisme tersebut, perlakuan terhadap buruh merupakan perlakuan yan bercorak memanusiakannya. Memanusiakan buruh berarti menghormati hak-haknya sebagai manusia. Pemenuhan terhadap hak-hak buruh yang dilakukan status kesederajatan dan perlakuan yang bercorak oleh majikan atau perusahaan merupakan kewajiban yang tidak hanya bermanfaat bagi buruh, tetapi juga bermanfaat bagi majikan atau perusahaan. Dalam doktrin Islam universal sudah dijelaskan, bahwa yang disebut manusia terbaik adalah manusia yang bisa memberikan manfaat bagi manusia lainnya, yang kemanfaatan ini bisa berkembang atau dikembangkan, yang salas satunya dalam bentuk kesejahteran progresif (kesejahteraan yang tidak bersifat instan, tapi terus menerus berkembang).

\section{KESIMPULAN}

Perkembangan hak-hak asasi manusia (HAM) buruh memang sudah mengalami peningkatan di beberapa aspek, seperti hak upah buruh, akan tetapi peningkatan atau perkembangan ini masih tetap belum seimbang jika dikaitkan dengar berkembang pesatnya kebutuhan sehari-hari buruh.

Kebutuhan sehari-hari buruh, terutama kebutuhan pokoknya merupakan kebutuhan. menjadi beban utamanya, sehingga mereka (buruh) masih belum mendapatkan dan menikmati hak kesejahteraan progresifitasnya dibandingkan dengan pengusaha yang secara umum bisa mendapatkan keuntungan lebih dari cukup, bilamana yang dipikirkan oleh pengusaha hanya bagaimana mendapatkan keuntungan berlipat ganda.

\section{DAFTAR RUJUKAN}

Abdul Haris, Berjuang Demi Nasib Buruh, Suara Karva, 1 Mei 2013, diakses 1 Mei 2013

Ahsan Abdullah, 2013, Islam dan Hak-hak Buruh, Pressindo-Press, Jakarta. Eko Riyadi, 2012, Perspektif Islam terhadap Hak Buruh, makalah, UII, Yogyakarta. Fadly Rahman, 2009, Buruh dalam Islam, hhttp://fadlyrahman.wordpress.com/2009/11/09/ buruh-dalam-islam/ Fajar-Online, 1 Mei 2013, akses 15 Mei 2013. Kabul. Imam. 2007. Agama dalam Semesta Pergulatan Manusia. Jakarta: Nirmana Media. 
Oksidelfa Yanto, Buruh dan Hak yang Masih Terabaikan, http://www.unisosdem.org/ article detailphpaid-10040\&coid-2\&cai 36\&gid-2

Sudarsono. 2007. "Hubungan Pengusaha danBuruh".http://herisudarsono07.multiply.com/journal/item/30/Hub ungan_Pengusaha_dan Buruh 